\title{
A CRITICAL EVALUATION OF THE SOLID WASTE MANAGEMENT SYSTEM IN SELECTED WARDS OF JANGIPUR MUNICIPALITY WITHIN THE MURSHIDABAD DISTRICT, WEST BENGAL, INDIA.
}

\author{
Das Sumana, ${ }^{1}$ Ghosh Manab ${ }^{2}$ \\ ${ }^{1}$ Department of Geography, Sidho-Kanho-Birsha University, Purulia, West \\ Bengal (INDIA) \\ ${ }^{2}$ Department of Geography, Krishnagar, Government College, Krishnagar, \\ Nadia, West Bengal (INDIA) \\ sumanadas712 [at] gmail.com, manabghosh37 [at] gmail.com
}

\begin{abstract}
Municipal solid waste (MSW), commonly known as garbage, refuses or rubbish, is waste consisting of everyday items that are discarded by the public. Rapid urbanisation in India accelerates the generation of MSW, thereby producing major problems with its disposal. Improper handling of MSW creates environmental and health related hazards. In this paper an attempt is made to evaluate the solid waste management within the Jangipur Municipality, a cantonment town of West Bengal. This paper portrays MSW generation, its collection, as well as the attention of local self-government to spreading diseases. The paper also highlights the issues and challenges related to MSW, while trying try to find out some scientific treatment for solid waste management.
\end{abstract}

Keywords: Municipal Solid Waste (MSW), Rapid Urbanization, Health Hazards, Scientific Treatment.

\section{INTRODUCTION}

Solid Waste Management may be defined as the discipline associated with the control of generation, collection, storage, transfer and transport, processing and disposal of solid wastes in a manner that is in accord with the best principles of public health, economics, engineering, conservation, aesthetics and other environmental considerations [1], [2]. According to Britannica, "Solid-waste management, the collecting, treating and disposing of solid material that is discarded because it has served its purpose or is no longer useful. Improper disposal of municipal solid waste can create unsanitary conditions in turn can lead to pollution of the environment and to outbreaks of vector-borne disease that is, diseases spread by rodents and insects." Municipal solid waste management (MSWM), a critical element towards sustainable metropolitan development, comprises segregation, storage, collection, relocation, transport, processing, and disposal of solid waste to minimize its adverse impact on environment [3]. Unmanaged MSW becomes a factor for propagation of innumerable ailments. MSWM is one of the most overlooked basic services provided by the Government 
of India. Characteristic of MS may vary at the level of country, state, city as well as various areas in of the same city. MSW generation rates range between 0.3 and $0.6 \mathrm{~kg} / \mathrm{capita} / \mathrm{day}$ in Indian cities and annual increase in MSW generation (volume) is estimated as $1.33 \% /$ capita [4], [5], [6], [7].

As per Municipal solid waste Management and Handling rules -2000 , solid waste management is in the mandatory function of urban local bodies, but in actual practice the solid waste management is given the last priority and the duties are either not performed or poorly performed consequently the city has to face numerous problems related to environment and sanitation (Position paper on PPP in Solid Waste Management 2009 Ministry of Finance, govt. of India). As per the reports of the committee constituted by the Hon'ble Supreme Court of India in March of 1999, the lack of financial resources, inefficient institutional arrangement, inappropriate technology, weak legislative measures and unawareness of the public towards solid waste management has made the service most unsatisfactory and inefficient (CPHEEO 2013, Ministry of Urban Development, govt. of India). The solid waste management approach in India is extremely inefficient, using an obsolete system, technology for storage, collection, processing, treatment and disposal. There is no formal organized system of segregation of biodegradable and non-biodegradable solid waste [8], [9], [10]. The recovery and recycling of waste is only done by scavengers and scrap dealers, which is highly hazardous to those involved in this job [9], [10]..

The Jangipur Municipality envisions itself by 2020 to become economically independent, with an equitable social structure and culturally rich community. The Municipality aims to alleviate poverty from the society, by providing all the basic services to citizens, irrespective of their religion, caste and economic status. Safe and adequate drinking water supply, good roads, adequate street lighting, improved drainage network and last but not the least important sanitation and proper solid waste management are among many other objectives, which the municipality vows to provide within the next five years.

This paper critically evaluates the present situation of MSWM system to develop a modern solid waste management system in future. Simple and efficient organization structure and long term innovative financial planning will serve the citizen better, while at the same time achieving adequate solvency for the Municipality, which has a long historical background and many ways to head towards a promising future.

\subsection{Study Area}

Jangipur is an old town having reference from the historical period of Jahangir when a Moughal army camp was established here [11]. A District Board was set up in 1865 and, before this, the Bengal Municipal Act had been passed in 1842. In 1869 Jangipur Municipal Board made its first appearance. The Municipality is located in Jangipur Subdivision of Murshidabad district in the Gangetic plain of West Bengal. River Bhagirathi, the tributaries of the Ganges River in West Bengal divide the Urban Local Bodies (ULB) in two separate halves, namely Jangipur and Raghunathgunj. The Jangipur part is under Raghnathganj-II block surrounded by ten-gram panchayats and three census towns. The total geographical area of the municipality is 8.20 square kilometres, which is divided into 20 Administrative 


\section{\#3/2018 URBAN CHALLENGES}

wards. Mean Coordinates of the municipality being $24028^{\prime} \mathrm{N}$ and $8804^{\prime \prime} \mathrm{E}$. The Raghunathgunj Police Station and Police Outpost namely, Raghunathgunj and Jangipur, situated within the boundary of the municipality. Jangipur is experiencing a high rate of urbanization. In Jangipur the urban population grew from 55,981 to 86,862 during the last 17 years, but this huge population lives only in $8.2 \mathrm{~km}^{2}$ area, thereby contributing to a population density of 10,593 per $\mathrm{km}^{2}$. The population in Jangipur is projected to increase at a fast rate and expected to reach 116,002 during the DDP period i.e. 2008-2012 and 222,403 in 2020, therefore producing a population density of 14,147 inhabitants per $\mathrm{km}^{2}$ and 27,122 inhabitants per $\mathrm{km}^{2}$, respectively [11], [12].

\subsection{Rationale Behind the Selection of the Area}

Just after the establishment of Jangipur, the municipality undertook a systematic plan for the drainage of this cantonment town. Then, the Executive Engineer designed the whole system of solid-waste disposal system. It was a century old system and definitely a wonderful example of engineering. This system is still working, but it needs proper reconstruction for more improved solid waste management, due to the growing population pressure on the town. For a detailed study on this topic, only three major wards were selected (cf. Figure 1).

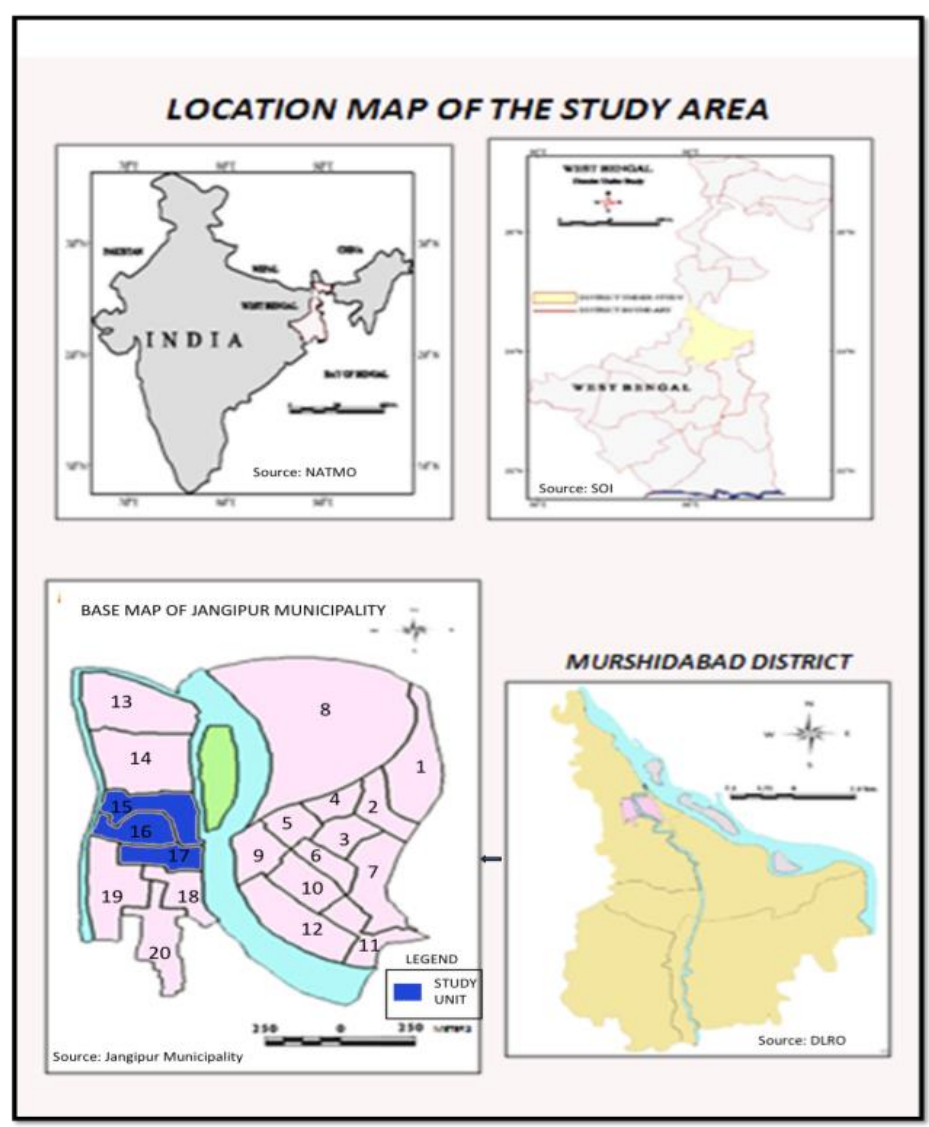

Figure 1: Location of the Study Area

Source: Various sources. 


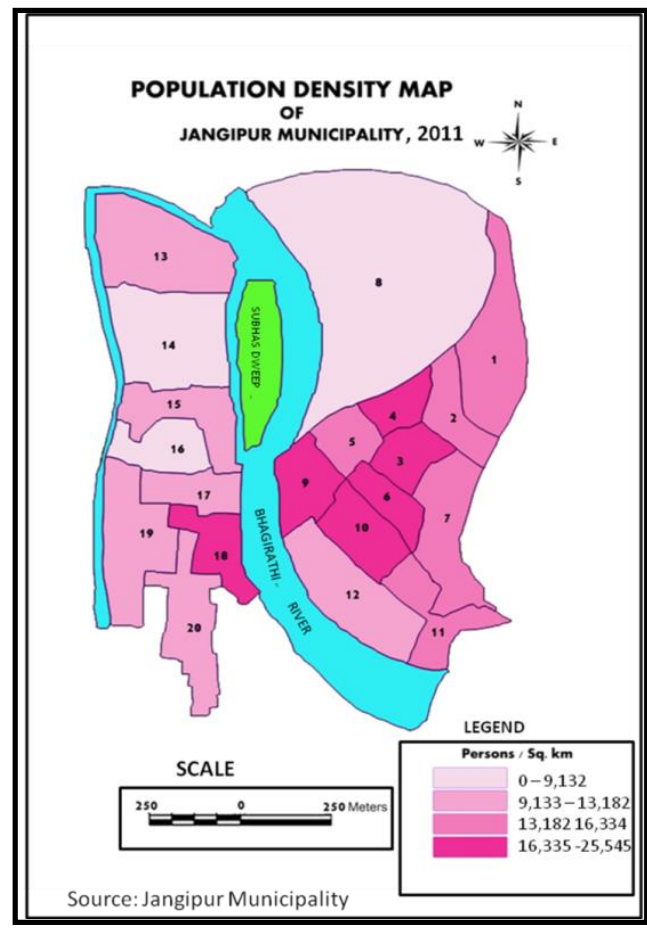

Figure 2: Population Densities within the Municipality of Jangipur Source: The Municipality of Jangipur.

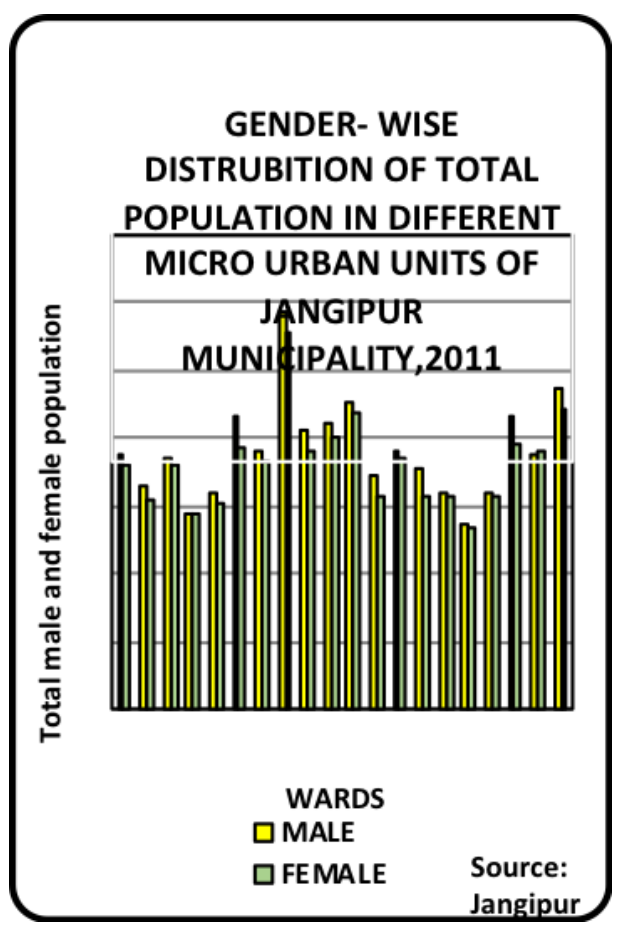

Figure 3: Gender Distribution within the Municipality of Jangipur Source: The Municipality of Jangipur. 


\section{\#3/2018 URBAN CHALLENGES}

\subsection{Aims of the Study}

This study has the following aims:

- To get a clear picture regarding the beneficiaries and non-beneficiaries of municipal waste-management system in the entire Jangipur Municipality;

- To draw attention of the Local Self Government concerning the spreading of diseases due to non-clearance of accumulated garbage from some areas of the Jangipur;

- To highlight the issues and challenges related to solid waste management in selected wards of the Jangipur Municipality;

- To point out the shortcomings of the Urban Local Body, regarding scientific treatment of the garbage generated regularly within the municipal arena.

\section{DATABASE AND METHODOLOGY}

Two types of database have been procured for making the project worthy. The first one is a secondary data-source where different reports, records, journals, gazetteers, periodicals on the specific problem have been perused and adequate information have been gathered from those literary sources. This information has been supported by primary data sources procured from the questionnaire survey. Purposive stratified sampling has been adopted to conduct the perception survey, with a hundred households being surveyed in each ward.

In order to conduct the primary survey, a hundred households have been chosen from each ward, in order to get the exact figure of respondents from the mastertable in percentage, regarding solid waste management related urban issues associated with this project. Thereafter, thematic maps and diagrams have been constructed based on the dataset obtained from the master table and inferences were drawn accordingly.

\section{DISCUSSION}

\subsection{Solid Waste Management}

Waste management is the "generation, prevention, characterization, monitoring, treatment, handling, reuse and residual disposition of solid wastes" [13]. There are various types of solid waste including municipal (residential, institutional, commercial), agricultural and special (health care, household hazardous wastes, sewage sludge). The term usually relates to materials produced by human activity, and the process is generally undertaken to reduce their effect on health, the environment or aesthetics.

To critically evaluate the scenario of solid waste management system in Jangipur municipality, detailed studies have been conducted that are given below: 
\#3/2018 URBAN CHALLENGES

\begin{tabular}{|l|c|}
\hline Waste types & $\begin{array}{l}\text { Waste generation at } \\
\text { the municipal level (\%) }\end{array}$ \\
\hline Large plastic bags & $35.19 \%$ \\
\hline Medium plastic bags & $51.85 \%$ \\
\hline Small plastic bags & $12.96 \%$ \\
\hline
\end{tabular}

Table 1: Types of Waste Generation

According to the Jangipur Draft development plan of 2012 [14], the types of waste generated by the municipality have been categorized in 3 types of polymer waste. Within the total waste generation above $50 \%$ are medium size plastic bags, $35 \%$ large plastic bags and $12 \%$ small sized plastic.

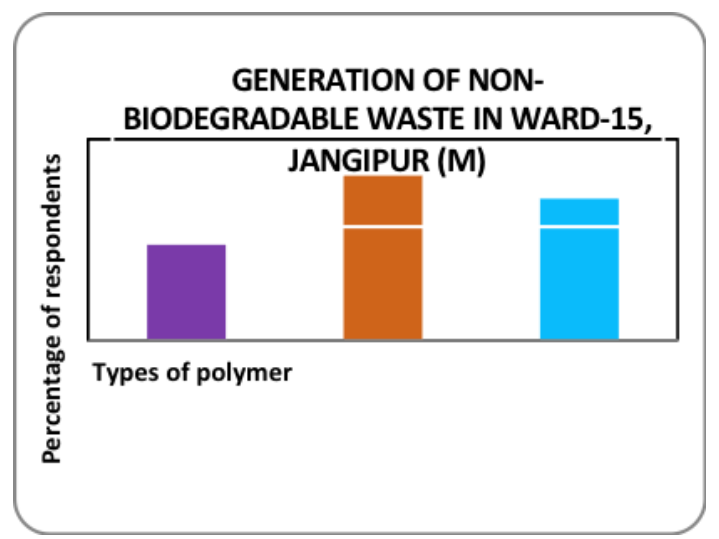

Figure 4 Generation of Non-Biodegradable Waste in Ward 15, Jangipur Source: The Municipality of Jangipur.

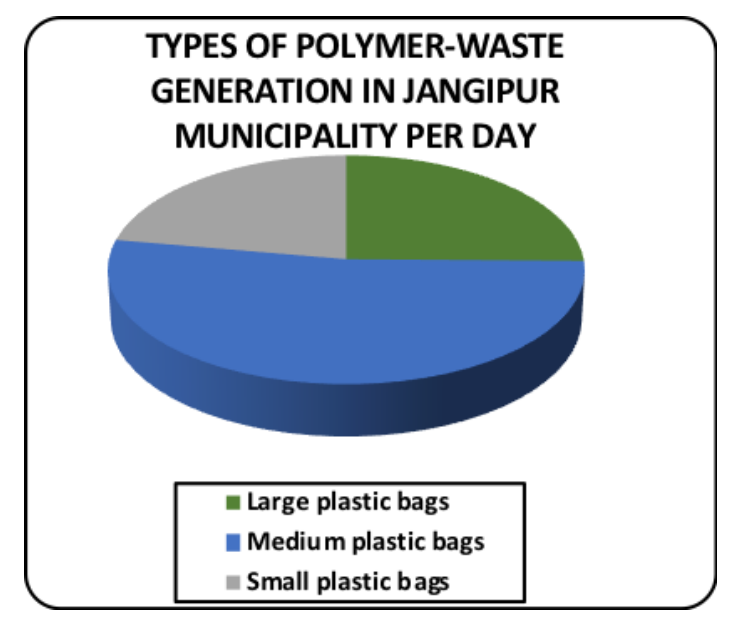

Figure 5: Types of Polymer-Waste Generation in Jangipur Municipality, per Day

Source: The Municipality of Jangipur. 


\section{\#3/2018 URBAN CHALLENGES}

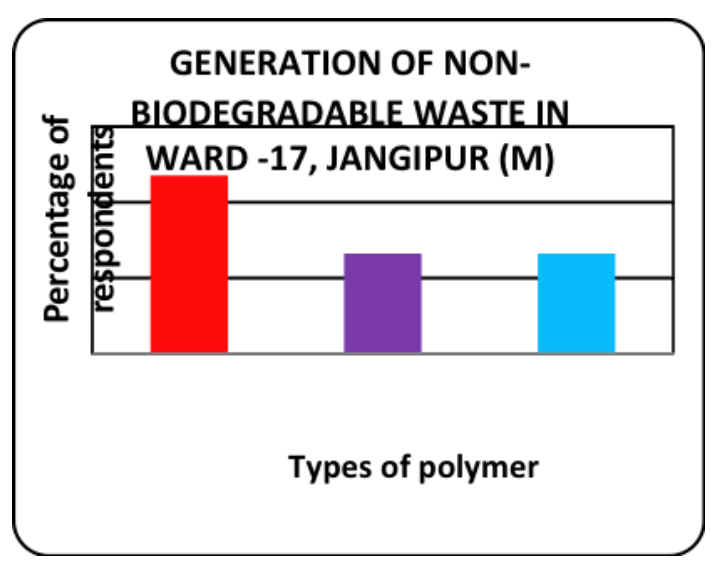

Figure 6: Generation of Non-Biodegradable Waste in Ward 17, Jangipur Source: The Municipality of Jangipur.

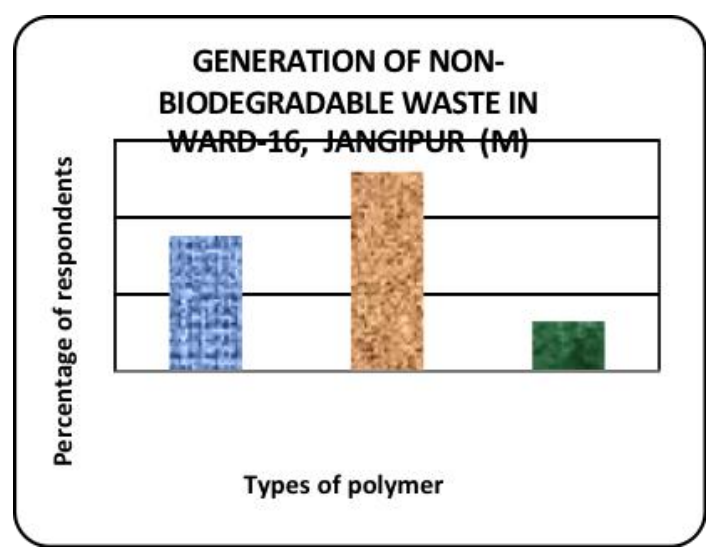

Figure 7: Generation of Non-Biodegradable Waste in Ward 16, Jangipur Source: Jangipur Draft Development Plan, 2012.

\subsection{Waste Disposal Strategies}

In the municipality there is $52 \mathrm{MT}$ SW is collected each day. It needs to be collected properly with due attention and recycled [12]. Solid Waste Management has to be taken into serious consideration, in order to maintain cleanliness. The waste needs to be converted into wealth. This is possible through the utilization of rapid advancement of science and technology. In the municipality, garbage is collected from roadside. Door to door collection has not yet been attempted. Garbage disposal is not done properly. There is no system of house-to-house collection. It is thrown here and there, even into the drains. The dumping ground has been in existence for the past ten years. There is a need of one more dumping ground. 


\section{\#3/2018 URBAN CHALLENGES}

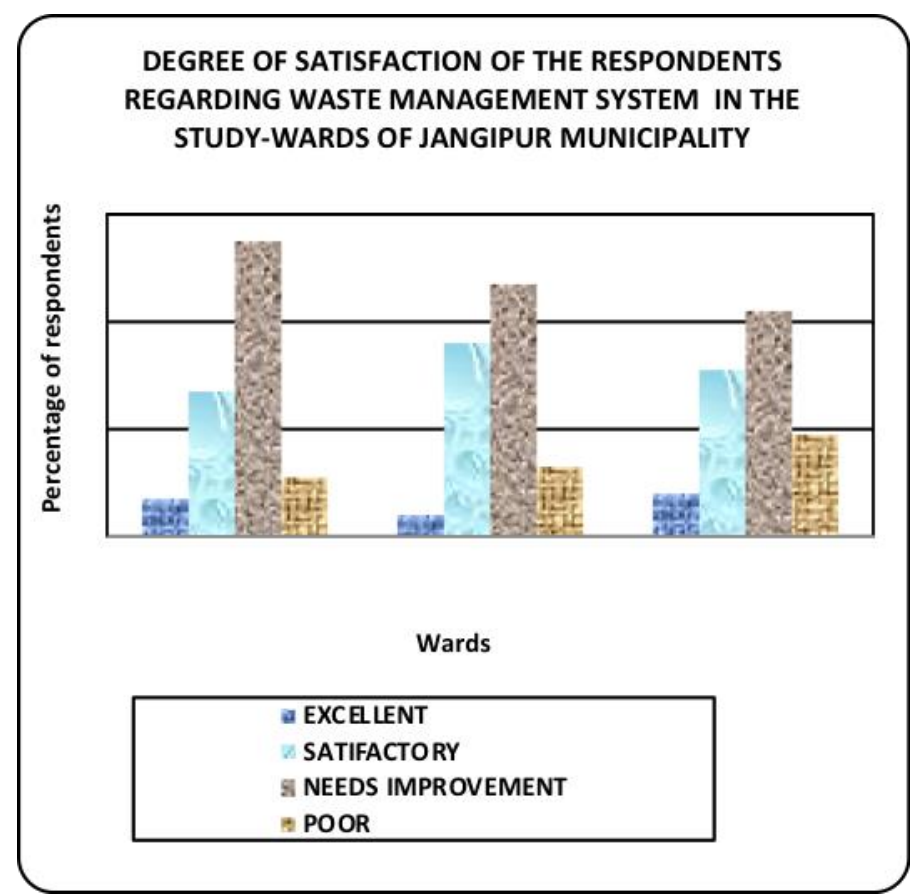

Figure 8: Degree of Satisfaction with the Waste Management System within the Study Wards

Source: The Author.

Now garbage disposal in the wards is becoming an important and significant issue for maintaining healthy and clean atmosphere. Permanent structures in term of vat at the various points of wards are needed where people can dispose of the garbage from their home. It was clearly mention in problem identification workshop. Operation and Maintenance is to be undertaken by the ULB involving ward committees respectively. The existing dumping ground is situated in ward no. 1 is causing environmental and health concern. The Ward Committee is willing to play the role in supervision, maintenance and operation. Recycling is also required which would create employment opportunities for the unemployed youths. 


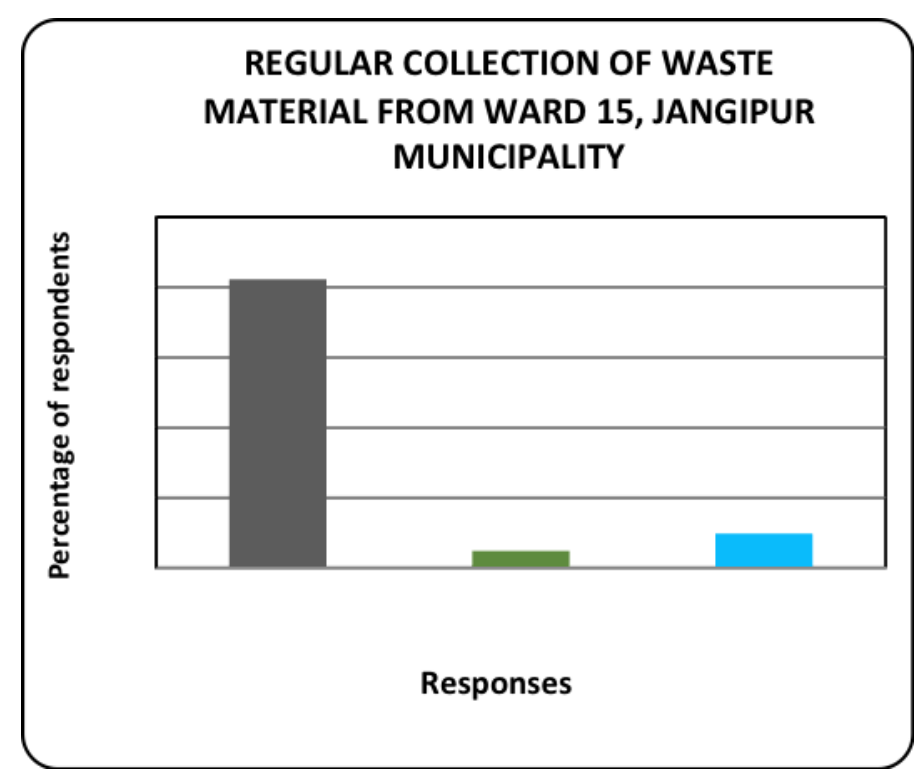

Figure 9: Regular Collection of Waste Material from Ward 15, Jangipur Source: The Municipality of Jangipur.

Special team has to be deployed for collection and disposal of waste during festivals in order to keep the festival places clean and hygienic. Vats have to be provided at the spots where the festivals took place. These would draw the attention of pilgrims during their visit to Jangipur Municipality on several occasions (Durga puja, Diwali, Saraswati puja, Eid, Maharam).

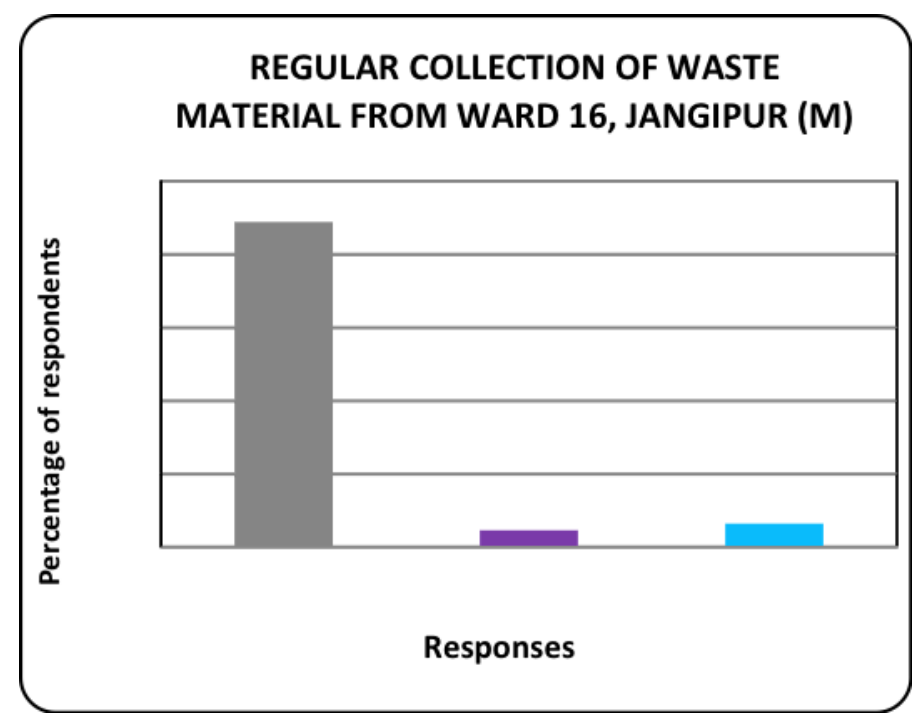

Figure 10: Regular Collection of Waste Material from Ward 16, Jangipur Source: The Municipality of Jangipur. 


\section{\#3/2018 URBAN CHALLENGES}

Introducing the waste disposal in a proper manner would draw attention of other persons belong to the upper strata of people and the tourism can be developed in the ULB.

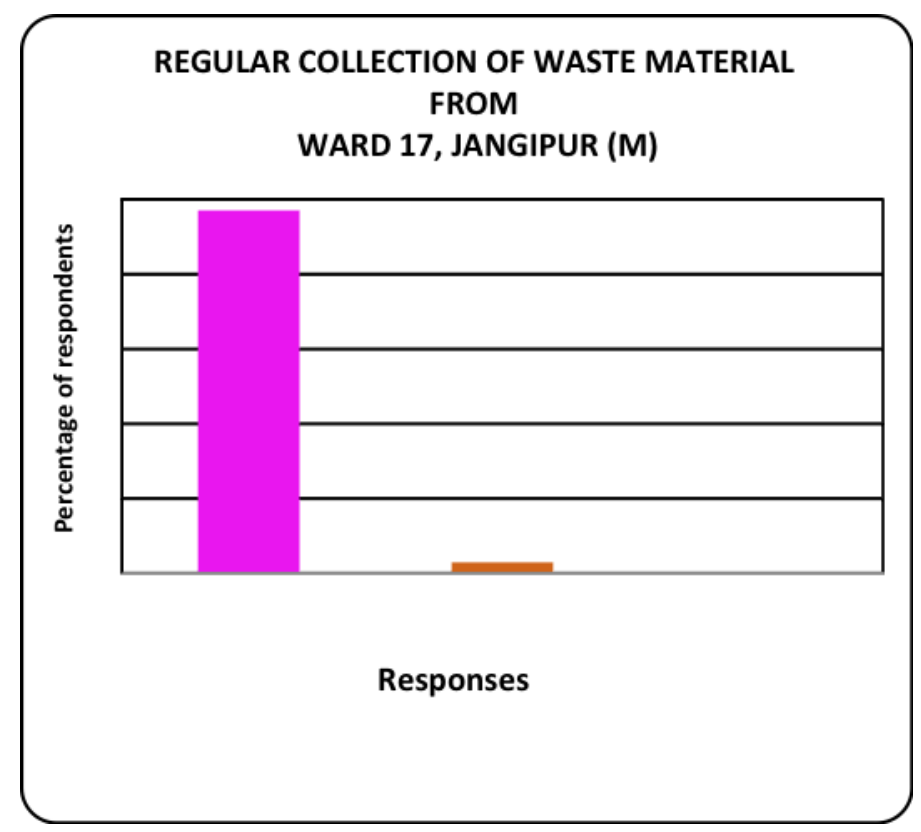

Figure 11: Regular Collection of Waste Material from Ward 17, Jangipur Source: The Municipality of Jangipur.

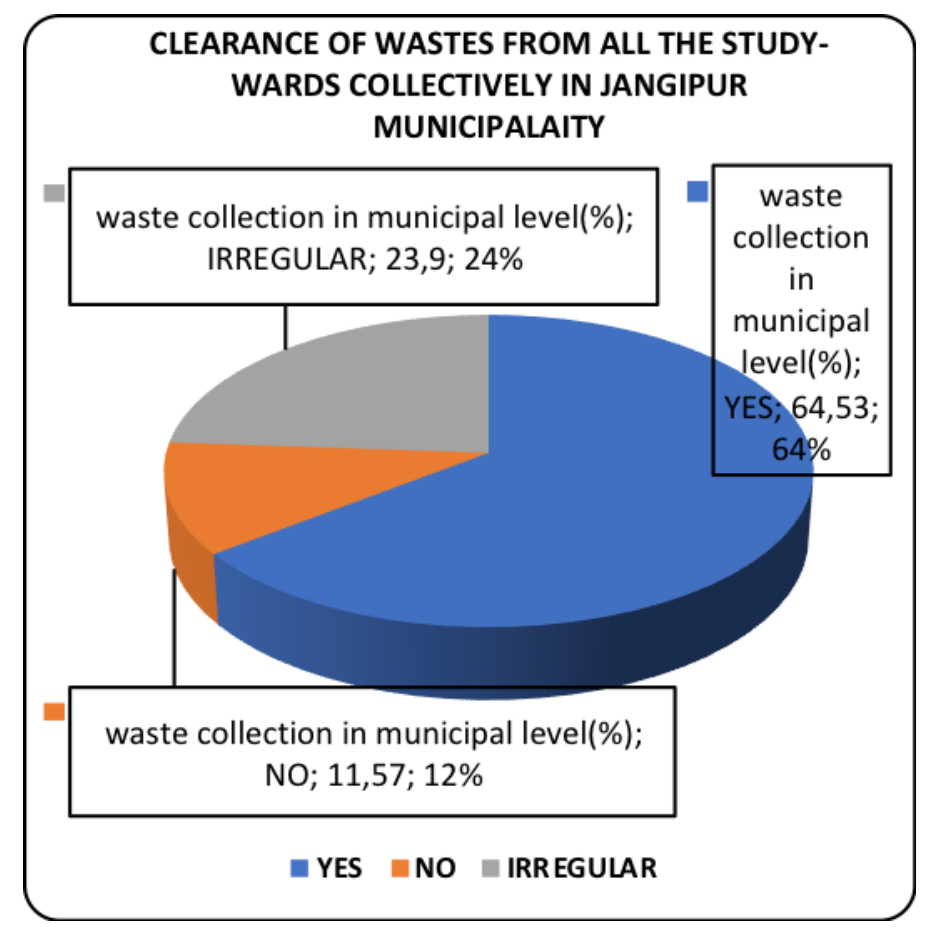

Figure 12: Clearance of Waste from All the Study-Wards

Source: The Municipality of Jangipur. 


\section{\#3/2018 URBAN CHALLENGES}

There are four types of garbage disposal systems found in Jangipur municipality. The respective diagram shows different types of garbage disposal methods in ward no. 15,16 , and 17 of Jangipur municipality. in ward no. 15, highest percentage (36\%) of households use disposal bins for the disposal of garbage. $15 \%$ of total surveyed households dispose garbage in open field. In case of ward no. 16, (45\%) of households use garbage disposal bin and on and around, $19 \%$ uses municipal van for disposing garbage. From the diagram, it's clear that in ward no. 17, highest percentage of households (36\%) use a municipal van.

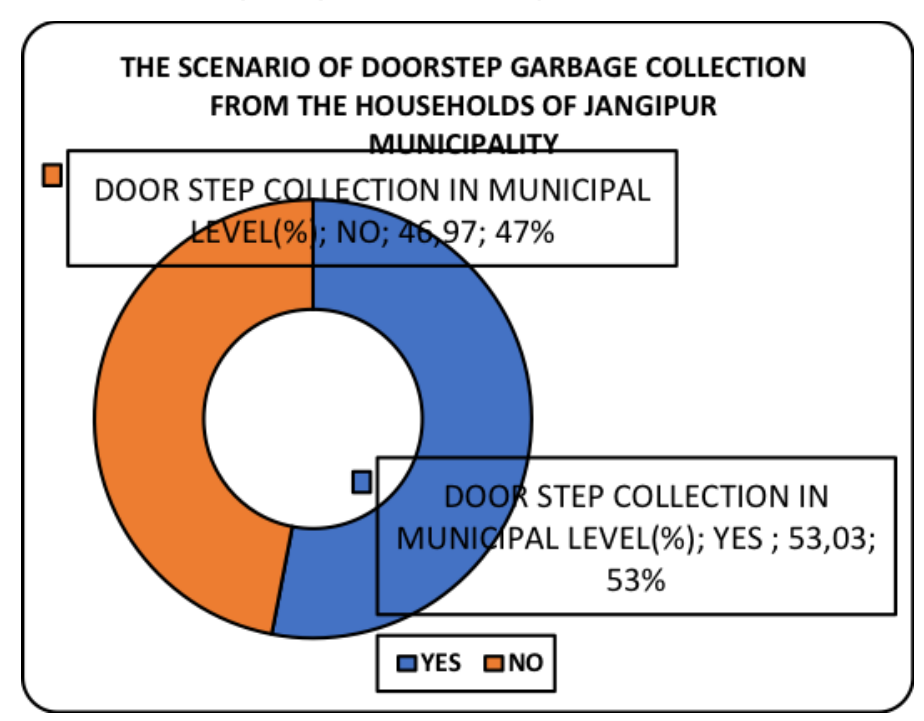

Figure 13: The Scenario of Doorstep Garbage Collection

Source: The Municipality of Jangipur.

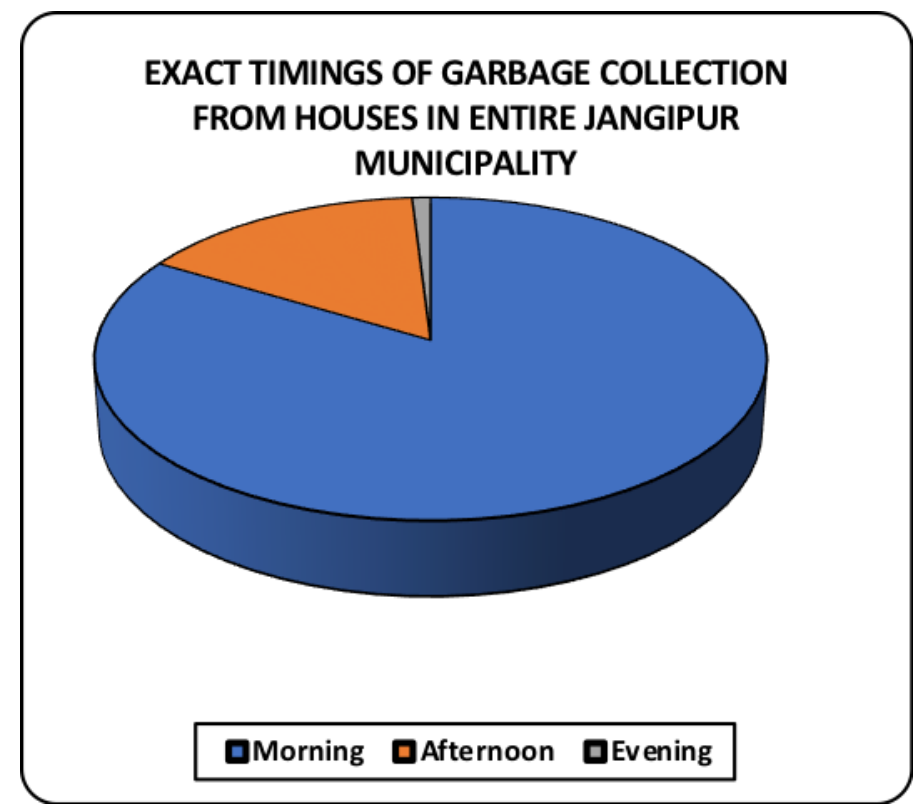

Figure 14: Exact Timings of Garbage Collection from Houses in Jangipur Source: The Municipality of Jangipur. 


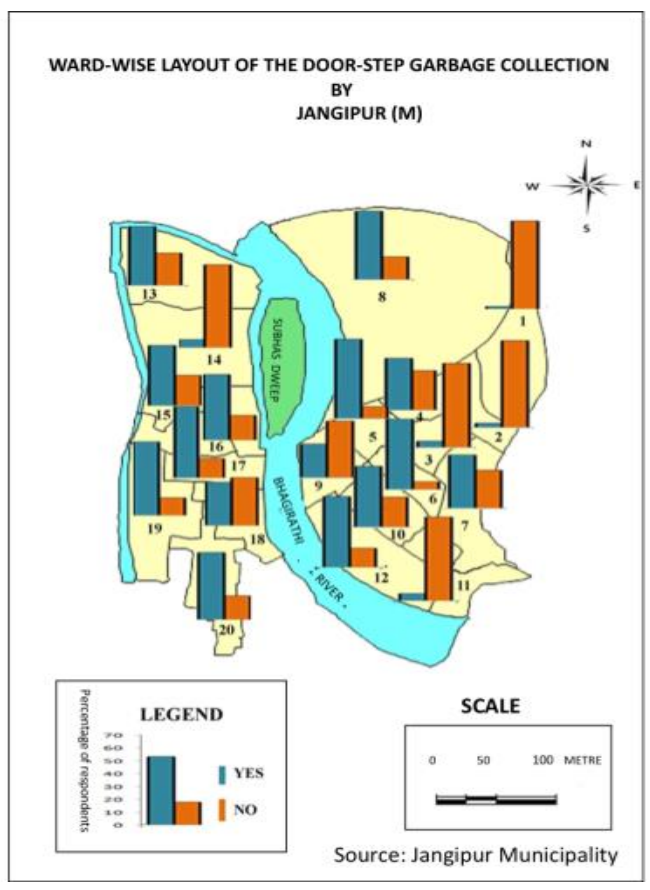

Figure 15: Ward-wise Layout of the Doorstep Garbage Collection in Jangipur

Source: The Municipality of Jangipur.

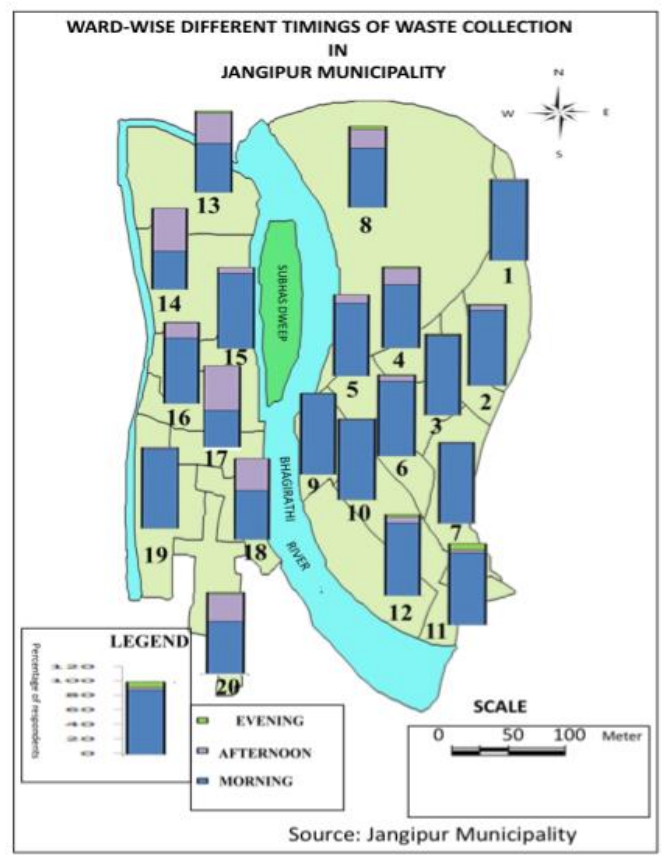

Figure 16: Ward-wise Timings of Waste Collection in Jangipur Source: The Municipality of Jangipur. 


\section{\#3/2018 URBAN CHALLENGES}

The diagram reveals that the respondents of households in a considerable number dispose garbage at roadside in Jangipur Municipality. In houses respectively of ward nos. 15,16 and $17,81 \%, 87 \%$ and $85 \%$ respondents don't dispose garbage at roadside and on the other hand, $19 \% 13 \%$ and $15 \%$ of total households respectively respondents dump garbage at roadside in those respective wards [11], [12].

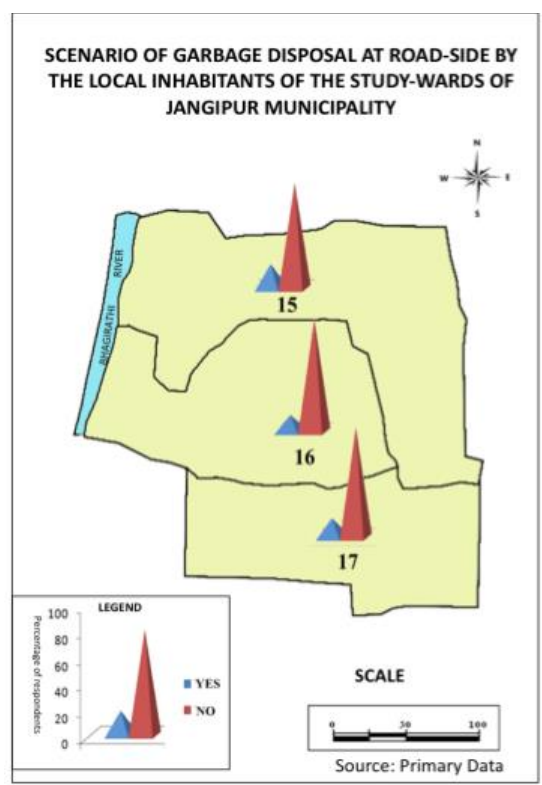

Figure 17: Scenario of Garbage Disposal at the Roadside

Source: The Author.

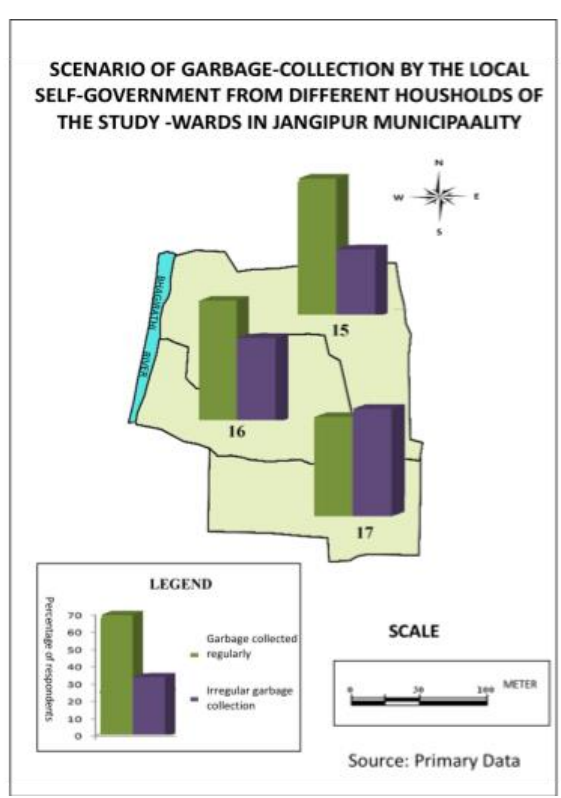

Figure 18: Scenario of Garbage Collection by the Local Self-Government Source: The Author. 


\section{\#3/2018 URBAN CHALLENGES}

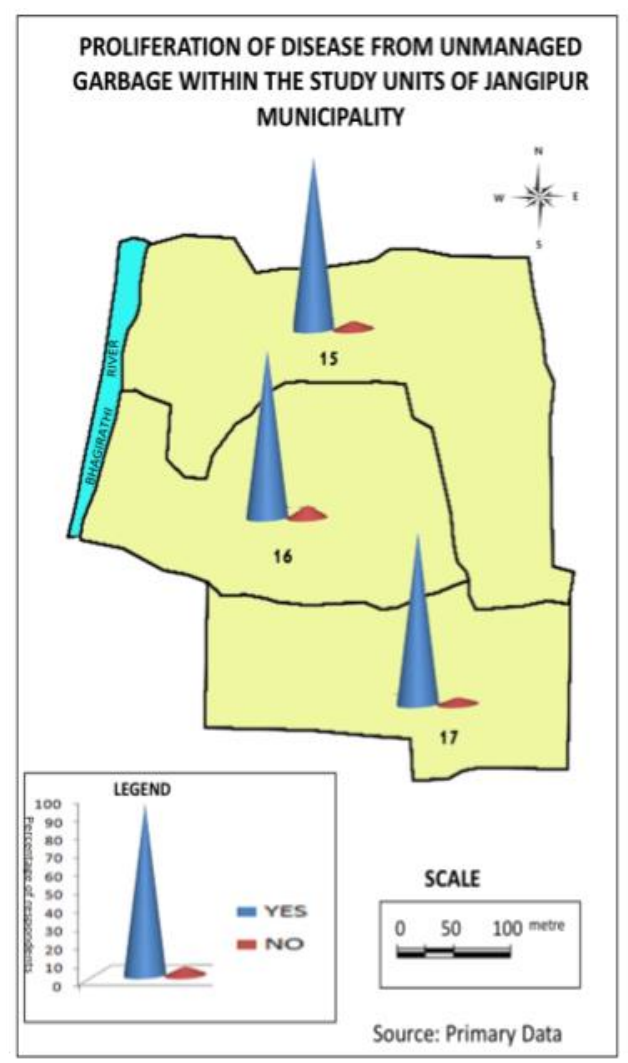

Figure 19: Proliferation of Disease from Unmanaged Garbage

Source: The Author.

The Municipality provides two types of garbage collection methods. They collect garbage from individual households and sometimes they do collect the same from that of damping ground. The accompanying diagram indicates that the high percentage of respondents of households in ward no. 15, 16 and 17 have said that their regular garbage is taken away by the municipality-staff from their individual houses. In ward no. 16, highest percentages of households (81\%) have responded that municipality-staff collect garbage from dumping ground (Primary data).

The diagram reveals that the proliferation of disease from unmanaged garbage is very alarming in Jangipur municipality. In houses respectively of ward no.15, 16 and 17 , within $80-90 \%$ respondents said that different types of diseases like; malaria, dengue, asthmatic disease etc. proliferated from these garbage [11], [12]. 


\section{\#3/2018 URBAN CHALLENGES}

\section{FINDINGS}

After the thorough questionnaire survey conducted in selected study-units of Jangipur Municipality and further verification of the primary databases with that of secondary ones, the researcher has reached to the following findings as well as conclusions and these are as follows.

\subsection{Problems of the Solid Waste Management within the Jangipur Municipality}

1. In Jangipur solid waste is disposed traditionally. Every family disposes of the solid waste on roadside, near the house. There is no segregation of solid waste. Waste is then dumped in open ground for land filling. Total land engaged for this purpose is growing, thereby becoming a nonproductive. Solid waste dumped openly on the common areas, so animals scattered anywhere. Local authority has no sufficient source for purchasing the vehicles. As well as high maintenance cost of vehicles. Collection of solid waste therefore becomes a crucial step in management of solid waste at Jangipur;

2. Garbage disposal systems are observed to be pretty satisfactory in ward no. 17 of Jangipur municipality;

3. The Local Self-government of Jangipur should pay adequate attention concerning a systematic garbage-clearance from the localities of ward no.-15 and ward number-16;

4. For scientific as well as an hygienic management of disposed garbage generated from the households regularly, the Urban Local Body of Jangipur will have to be more and more forward and awareness should also be generated through campaigning amongst the inhabitants of this Municipality, by the direct initiative from the end of its administrative authority.

\subsection{Possible Solutions to the Solid Waste Management in Jangipur}

Unfortunately, a normally developing country like India does not have any proper solid waste management system in every municipal area. As a consequence, within the Jangipur Municipality, problems related to solid waste management arise. 


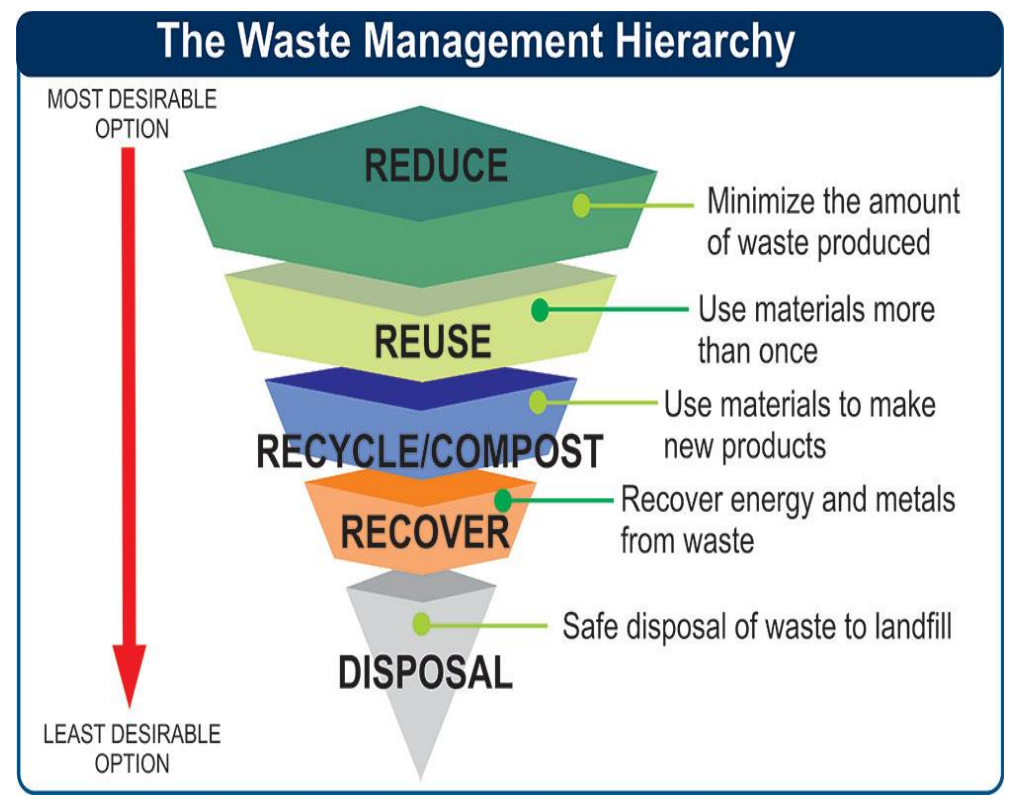

Figure 20: The Waste Management Hierarchy

Hence, for the proper management of MSW within the Jangipur municipality, one appropriate way is to develop a sustainable waste management system. In this system MSW have been managed by reduce, reuse and recycle mechanism. There are many environmental benefits that can be derived from the use of these methods. They reduce or prevent greenhouse gas emissions, reduce the release of pollutants, conserve resources, save energy and reduce the demand for waste treatment technology and landfill space. Therefore, it is advisable that these methods be adopted and incorporated as part of the waste management plan.

The Hierarchy of Sustainable Waste Management developed by the Earth Engineering Center at Columbia University is widely used as a reference to sustainable solid waste management and disposal [15]. This study is presented in reference to this hierarchy. "Unsanitary Land filling and Open Burning" has been added to the original hierarchy of waste management which ends with sanitary landfills (SLFs). Unsanitary landfilling and open burning will represent the indiscriminate dumping and burning of MSW and represents the general situation of SWM in India and other developing countries. 


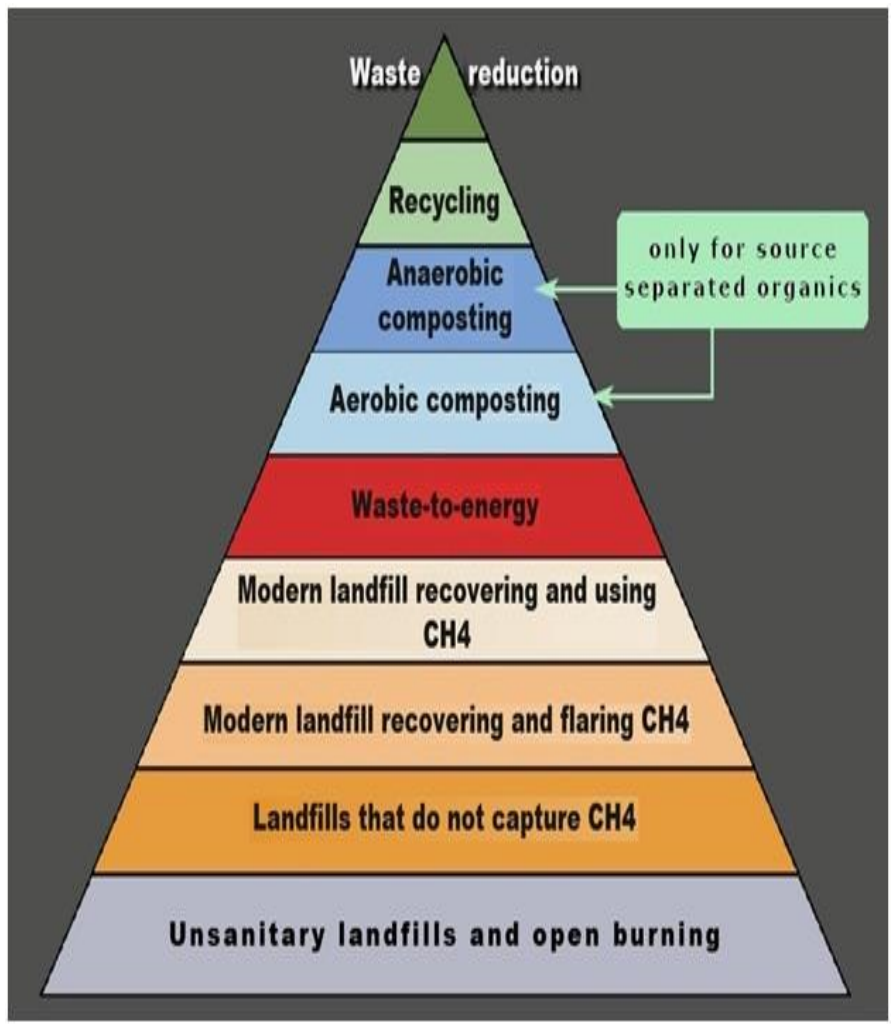

Figure 21: The Hierarchy of Sustainable Waste Management for India and Other Developing Nations [10]

\section{CONCLUSION}

The existing solid waste management system in Jangipur municipality is effective in carrying out the functions of primary collection and transport. These wastes are used only for landfilling purposes and open burning. But this system is not sustainable and for this after a time the city environment has been totally destroyed. Finally concludes that the problem of solid waste needs some holistic approaches such as reuse of solid waste to produce energy and bio manures. 


\section{References}

[1] Rao, M. N., Sultana, R., Kota, S. H., Shah, A. and Davergave, N. (2017), Solid and Hazardous Waste Management, Butterworth-Heinemann, Kidlington (OX).

[2] LeBlanc, R. (2017), "An Introduction to Solid Waste Management. Integrated Approach Needed for Successful Diversion and Recycling", The Balance. Available at: https://www.thebalancesmb.com/an-introduction-to-solid-waste-management2878102 [03.06.2018].

[3] Joshi, R. and Ahmed, S., "Status and Challenges of Municipal Solid Waste Management in India: A Review", Cogent Environmental Science, 2, 1, pp. 1-18.

[4] Pattnaik, S. and Reddy, M. V. (2010) "Assessment of Municipal Solid Waste Management in Puducherry (Pondicherry), India", Resources, Conservation and Recycling, 54, 8, pp. 512-520.

[5] Srivastava V., Ismail S. A., Singh. P. and Singh R. P. (2014), "Urban Solid Waste Management in the Developing World with Emphasis on India: Challenges and Opportunities", Reviews in Environmental Science and Bio/Technology, 14, 2, pp. 317-337.

[6] Syamala Devi, K., Swamy, A. V. V. S. and Nilofer, S. (2016), "Municipal Solid Waste Management in India - An Overview", Asia Pacific Journal of Research, I, XXXIX, pp. 118-126.

[7] Agarwal, A., Agarwal, M., Mehta, A. and Bajpai, M. (2016), "A Review on the Present Status of Municipal Solid Waste Management", SSRG International Journal of Civil Engineering, 3, 5.

[8] Kaushal, R. K., Varghese, G. K. and Chabukdhara, M. (2012), "Municipal Solid Waste Management in India-Current State and Future Challenges: A Review", International Journal of Engineering Science and Technology, 4, 4, pp. 1473-1489

[9] Dutta E. A B. (2015), "Review of Solid Waste Management in India", International Journal of Engineering Researches and Management Studies, 2, 5, pp. 51-57.

[10] Vanlalmawii, E. and Awasthi, M. (2016), "Municipal Solid Waste Composting A Review", International Journal of Advances in Science Engineering and Technology, 2, 1/1, pp. 13-16.

[11] Draft Development Plan (2002-2007), Jangipur Municipality, Murshidabad District.

[12] Draft Development Plan (2007-2012), Jangipur Municipality, Murshidabad District.

[13] Derbali, A. and Toumi, O. (2014), "The Management of Industrial Waste by Recycling in Tunisia", International Journal of Innovation and Scientific Research, 7, 2, pp. 140-154. 


\section{BIBLIOGRAPHY}

Ahuja, R. (2001), Social Problems in India (2 ${ }^{\text {nd }}$ Ed.), Rawat Publications, Jaipur (RJ).

Burgel, E. E. (1955), Urban Sociology, McGraw-Hill, New York (NY).

Danda, A. K. (1995), Urbanization and Slums, Har Anand Publication, New Delhi.

Desai, A. R. and Pillai, S. D. (Eds.) (1970), Slums and Urbanisation, Popular Prakashan, Bombay.

District Statistical Handbook (2007-2012), Murshidabad District, Bureau of Applied Economics and Statistics, Salt Lake, Kolkata.

Government of India, Ministry of Home Affairs, Office of the Registrar General and Census Commissioner, India, Census of India, 2011. Available at: http://censusindia.gov.in/2011-Common/CensusData2011.html [03.06.2018].

Kadam, M. S. and Sarawade, S. S. (2016), "Study and Analysis of Solid Waste Management Challenges and Options for Treatment (Indian Villages)", IOSR Journal of Mechanical and Civil Engineering, pp. 15-22.

Miezah, K., Obiri-Danso, K., Kádár, Z., Fei-Baffoe, B. and Mensah, M. Y. (2015), "Municipal Solid Waste Characterization and Quantification as a Measure Towards Effective Waste Management in Ghana", Waste Management, 46, pp. 15-27.

Parvathamma, G. I. (2014), "An Analytical Study on Problems and Policies of Solid Waste Management in India - Special Reference to Bangalore, IOSR Journal of Environmental Science, Toxicology and Food Technology, 8, 10, pp. 6-15.

Schwarz-Herion, O., Omran, A. and Rapp, H. P. (2008), "A Case Study on Successful Municipal Solid Waste Management in Industrialized Countries by the Example of Karlsruhe City, Germany", Journal of Engineering Annals of Faculty of Engineering Hunedoara, VI, 3, pp. 266-273.

Thomas, J. and Wilson P. M. (2013), "Construction Waste Management in India", American Journal of Engineering Research, 2, pp. 6-9.

United Nations Human Settlements Programme (UN-Habitat) (2003), The Challenge of Slums. Global Report on Human Settlements 2003, Earthscan, London. Available at: https://unhabitat.org/books/the-challenge-of-slums-globalreport-on-human-settlements-2003/ [03.06.2018].

Article distributed under a Creative Commons AttributionNonCommercial-NoDerivatives 4.0 International License (CC BY-NC-ND).

Received: January 22, 2018

Accepted: April 20, 2018. 